\section{有人宇宙活動における 高分子機能膜の利用}

\author{
小口美津夫 \\ 航空宇宙技術研究所
}

スペースシャトルの実用化以来，人類にとって宇宙は身 近なあのになってきている，そして現在，米国を中心とし て, 日本，ESA，カナダ，ロシアの国際協力のもとに恒久 的な有人宇宙ステーション (ISS) の建設が，1998 年 11 月 から始まり，2004 年には本格的な運用が開始され，人類 の活動の場はますます広がる.さらに 21 世紀にはいると， 月面基地の建設, 火星への有人飛行, 一般人の宇宙観光旅 行などが計画されており，大勢の人間が宇宙で自由に生活 する時代がやってくる.

人間が宇宙で生きるための生命維持システムは，現在は 使い捨て型のあのである.すなわち, 生命維持に不可欠な, 食料, 酸素, 水などの物資は地球加ら運搬している. 宇宙 活動におけるこれらの必要量はNASA の試算では, 1 日 あたり食料 $618 \mathrm{~g}$, 酸素 $836 \mathrm{~g}$, 飲料水 $3,077 \mathrm{~g}$ ，その他生 活用水が $25 \mathrm{~kg}$ となっている. 人間 1 人が 1 年間宇宙で生 活しようとすると,これらの必要物質の量は約 11 トンに あなり, シャトルでの運搬コストは 400 億円とも 500 億 円とあいわれ，膨大な輸送経費がかかる，さらに，人間が 生活するということは，必ずさまざまな廃棄物が発生する ことになり，その処理も深刻な問題となる。

運搬コストを下げ，安全に効率よく宇宙での生存環境を 構築する技術が閉鎖生態系生命維持システム (CELSS: closed ecological life support systems) というあので, 生 物系と物理化学処理系を組み合わせ，その環境内を循環す るさまざまな物質のバランスを制御しながら, 人間の生存 環境を人工的に構築し，外部からの物資を補給せずに，人 間が生活していこうというあのである.

CELSS の中で，高分子機能膜は主として気体や液体の 分離に用いられる. 宇宙実験での一番大きな問題は, 無重 量環境である. 地上では重力があるため, 液体どうしの分 離や気体と液体の分離は密度差が利用でき, 比較的簡単で ある. 無重量環境では回転による遠心力を利用すれば分離 ができるが，システムの信頼性や構造の簡素化を考える と，できるだけ機械部分は少ないことが望ましい，では，
具体的にどのようなところで高分子機能膜を利用するかを 紹介する。

人間や動物は生きていくために，酸素を消費し二酸化炭 素 $\left(\mathrm{CO}_{2}\right)$ を排出している. 閉鎖環境では, この $\mathrm{CO}_{2}$ を使っ て酸素を再生しなければならない，そのためには，植物の 光合成機能を利用する生物学的方法と, $\mathrm{CO}_{2}$ の還元によっ て得られる水を電気分解する物理化学的方法がある.

植物の光合成効率はあまり高くなく，たとえば稲によっ て人間 1 人 1 日あたりの必要酸素量を賄うためには，約 $40 \mathrm{~m}^{2}$ の栽培面積を必要とする. ところが，光合成藻類の 場合は，効率よく酸素を生産するので狭い空間での培養が 可能となる，これを実証するために，藍藻に属する「スピ ルリナ」を用いた培養実験を行っている，無重量環境での 実験を想定して，培養装置は密閉式である，光合成に必要 な光は, 光ファイバーを用いて効率よく供給している.

光エネルギーと無機栄養塩類, $\mathrm{CO}_{2}$ を利用して「スピル リナ」が光合成を行う之, 酸素が発生する. 培養容器は密 閉式のため，発生した酸素はすぐに気泡を形成する。この 酸素の気泡を培養液から分離するために，高分子機能膜を 利用している．このときに使用する膜が疎水性の中空糸多 孔質膜である. 膜の素材はポリエチレン製で，内径 900 $\mu \mathrm{m}$, 膜厚 $170 \mu \mathrm{m}$, 空孔率 $67 \%$ の中空糸を束ねて, 膜面 積が $0.2 \mathrm{~m}^{2}$ のモジュールとしている.この膜モジュール によって，6L の培養容積で平均濃度が $70 \%$ 以上の酸素 を毎分 100 150 mL 回収することができた．実験では酸 素の消費者として魚を選定し，密閉式の魚類飼育装置と結 合しているが，魚に必要な酸素供給にも膜モジュールを人 工肺として利用している．また航空機を用いた微小重力実 験においても，中空糸膜による気液分離を実証することが できた.

その他 CELSS では，酸素や $\mathrm{CO}_{2}$ のガス分離，廃水浄化 に膜を利用する. $\mathrm{CO}_{2}$ の還元では, 多孔質物質を用いて環 境中の $\mathrm{CO}_{2}$ の分離濃縮を行っているが，濃度が数\%以下 の $\mathrm{CO}_{2}$ を膜によって $95 \%$ 以上に濃縮できると，システム の簡素化が図れる。ささらに，廃水浄化に抢いてあ，長寿命 性，省エネルギー性をもつ膜が求められている。

Mitsuo OGUCHI，革新宇宙プロジェクト推進センター・主任研究官. 専門=宇宙システム工学, 宇宙生物学.

Utilization of Functional Polymer Membrane in Manned Space Activities 